\title{
Fullerene Black in Soot: Morphology vs. Electronic Structure.
}

\author{
J.-O. Müller, D.S. Su, R. Schlögl \\ Department of Inorganic Chemistry, Fritz-Haber-Institute of the MPG, 14195 Berlin, Germany
}

The particulate soot in the exhaust of diesel engines is subject to increasing criticism for being a serious threat to air quality and a potential risk to public health [1]. The current particulate standard will be tightened in 2005 for heavy duty engines [2]. Engine manufactures have started timely and intensively development of new low-emission engines and novel exhaust treatment systems together with catalyst manufactures. A system to reduce soot particles with a temporarily particle deposition on a filterless system with continuous regeneration is developed. The aim is a soot free diesel engine without particle filter to reach the EURO IV/V emission standard.

Soot is sampled on an EURO-IV diesel engine and investigated by HRTEM and EELS. Core-shelled spherical primary particles are found as described in the literature [3]: a core is approximately $5 \mathrm{~nm}$ in size and the shells consist of layered graphene system with radial symmetry. These graphene layers are defect rich and bended. This bending is due to incorporation of penta- or heptagons in the hexagonal graphite structure. The most of the soot particles do not exhibit this defined structure. The high-resolution imaging reveals fullerene-like clusters or molecules on the surface of the primary particles and can be, as PAH and organic radicals, considered as possible nuclei and source for the formation of soot. Moreover, fullerenoid carbons collide and coagulate to large particulates (Fig. 1)

The electron energy loss spectroscopy reveals apart of carbon, the origin of calcium due to ash formed during the combustion of lubrication oil in the engine. The near edge fine structure of the measured carbon-K-edge reveals differences in the electronic structure of the particulates due to the bonding of carbon atoms $\left(\mathrm{sp}^{2}\right.$ and $\left.\mathrm{sp}^{3}\right)$. The K-edges also show features from amorphous and graphite like carbon (Fig. 2). It is established that different bonding properties of the soot will lead to a different oxidation behaviour [4]. The quantification of the amount of $\mathrm{sp}^{2}$ and $\mathrm{sp}^{3}$ bonded carbon (Fig. 3) in diesel engine soot will be presented.

\section{References:}

[1] U.S. Environmental Protection Agency (EPA). (2002) Health assessment document for diesel engine exhaust. Prepared by the National Center for Environmental Assessment, Washington, DC, for the Office of Transportation and Air Quality; EPA/600/8-90/057F. Available from: National Technical Information Service, Springfield, VA; PB2002-107661, and http://www.epa.gov/ncea $>$.

[2] a) CONCAWE, 1994, Motor Vehicle Emission Regulation and Fuel Specification-1994 update, Brussels, pp234 and b) http://www.dieselnet.com/standards (2003)

[3] W.J. Grieco, J.B. Howard, L.C. Rainey, J.B. Vander Sande, Carbon 38, (2000) 597

[4] H. Werner, D. Herein, J. Blöcker, B. Henschke, U. Tegtmeyer, Th. Schedel-Niedrig, M. Keil, A.M. Bradshaw, R. Schlögl, Chemical Physics Letters 194 (1992) 62

Acknowledgement

This work is part of the project „Katalytisches System zur filterlosen kontinuierlichen Rußpartikelverminderung für Fahrzeugdieselmotoren“ supported by the Bayerische Forschungsstiftung, Munich. The authors thank Dr. E. Jacob and D. Rothe for providing the soot samples 


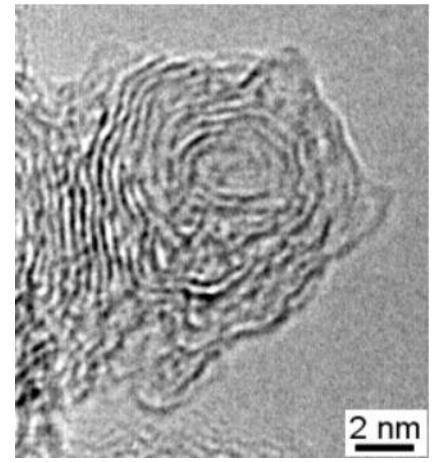

a)

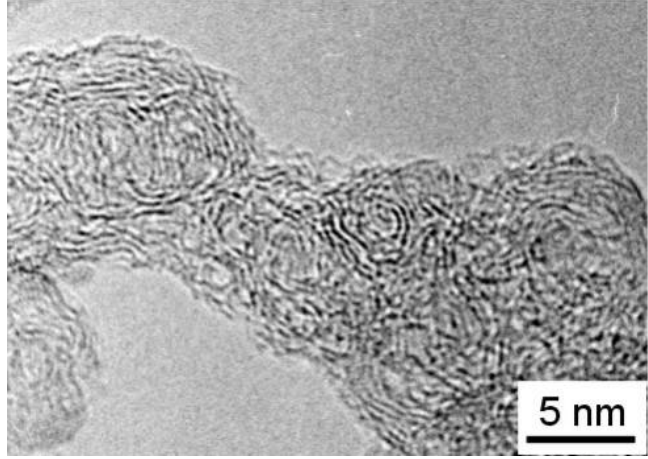

b)

Fig. 1: a) Particle with deformed and bended graphene layers,

b) fullerenoid agglomerate

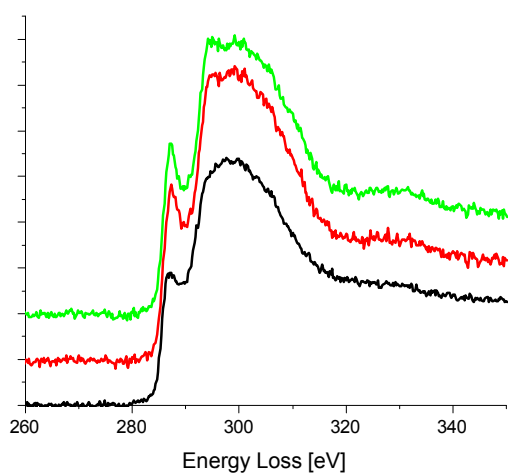

a)

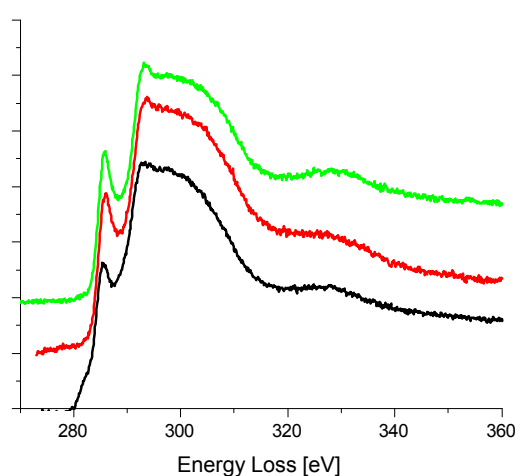

b)

Fig.2: EELS measurements on a) fullerenoid soot and

b) soot from a diesel engine operating at black smoke conditions

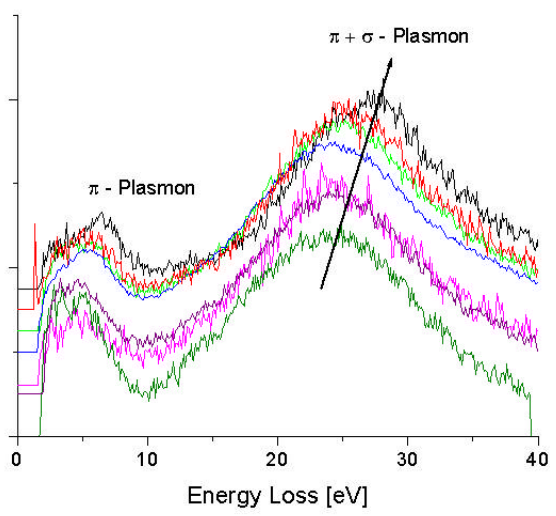

a)

\begin{tabular}{lc|c} 
& Ep [eV] & Nsp3 [\%] \\
\hline \hline Furnace Soot & 24,2 & 11,6 \\
HBC C ${ }_{42} \mathrm{H}_{18}$ & 24,4 & 6,6 \\
Diesel Engine Soot & 24,7 & 17,9 \\
P1 & 25,1 & 23,9 \\
Lamp Black & 25,3 & 25,7 \\
Cs-Pyrolysis & 25,6 & 29,7 \\
Graphite & 27,0 & 48,7 \\
\hline
\end{tabular}

b)

Fig.3: a) Plasmon measurements and b) derived $\mathrm{sp}^{3}$-contents from carbonaceous materials 